\title{
How should textbook analogies be used in teaching physics?
}

\author{
Nilüfer Didiş Körhasan ${ }^{1, *}$ and Mustafa Hıdır ${ }^{2}$ \\ ${ }^{1}$ Faculty of Education, Zonguldak Bülent Ecevit University, 67300 Zonguldak, Turkey \\ ${ }^{2}$ Dağlıca Elementary School, 67300 Zonguldak, Turkey
}

(Received 5 September 2018; published 4 February 2019)

\begin{abstract}
Analogies are suitable for teaching scientific concepts by comparing an unknown with a known. For this reason, they are widely used by textbook authors or science teachers for different aims such as introduction, clarification, or discrimination of new concepts. This study examines the analogies used in elementary science textbooks from 3rd to 8th grades and criticizes the use of analogies. By considering Glynn's teaching-with-analogies approach, this study identifies the missing parts of the analogies that should be revised and presents examples of how textbook analogies could be improved by teachers in teaching physics concepts.
\end{abstract}

DOI: 10.1103/PhysRevPhysEducRes.15.010109

\section{INTRODUCTION}

Science educators need various practical teaching techniques when teaching science. "Analogies" are important in science teaching, with analogy being a practical technique [1] explaining unknown phenomena using the properties of known phenomena by making comparisons [2]. Known phenomena are termed "analog" and unknown ones are referred to as "target" [3,4]. Analog and target share some common characteristics called "attributes" [5], which allow the construction of relationships. In this manner, similarities are presented by comparing known $A$ (analog) with unknown $B$ (target), a process referred to as "mapping" [5]. At that point, analogies are considered an instructional technique in determining meaningful relationships between prior and new knowledge [1].

Throughout the history of science, analogies have been used to understand new concepts and explain them to others. For example, the "plum pudding" analogy of Thomson or the "solar system" analogy of Rutherford to describe an "atom" had important roles in the understanding and teaching of atoms. While Stephen Hawking used approximately 70 analogies in his book A Brief History of Time to explain astrophysics and quantum ideas, many scientists such as Oppenheimer, Maxwell, Boyle, Huygens, and Kekule contributed to the development of science by using analogical thinking in their discoveries [6]. Analogies can be used to understand difficult concepts and to make abstract concepts more concrete [7]. The use of

niluferdidis@gmail.com

Published by the American Physical Society under the terms of the Creative Commons Attribution 4.0 International license. Further distribution of this work must maintain attribution to the author(s) and the published article's title, journal citation, and DOI. analogies in the teaching of abstract and difficult concepts may help students' conceptualization; however, analogies are considered double-edged swords - if not used carefully, they may cause misconceptions [6,8-11], particularly when the analogy breaks (i.e., when the analog and target do not share similar features), students may transfer dissimilar parts of the analogies to their learning and consequently misunderstand taught concepts [12]. Thus, not only is it important to consider which analogies are used in the teaching of scientific concepts, but also how analogies are constructed and used in textbooks and science classes.

The literature is rich in analogy use in science. Research regarding analogies can be categorized as (i) use of analogies in science classes and conceptual learning [1,8,13-16], (ii) use of analogies in science textbooks [5,17-21], (iii) different approaches in analogy use in science classes [4,5, 22-26], (iv) knowledge and opinions of science educators about analogies and their use [25,27-31], (v) knowledge and opinions of students about analogies and their use [32-35], and (vi) new analogies constructed by science educators [8,36-38]. Among these categories, the second category is studied with the analyses of textbooks of different disciplines such as chemistry, biochemistry, and physics and with different grade levels such as elementary, secondary, and university levels. While these analyses indicated variation in the average number of the analogies per textbook and presented the analogy use with different properties [5, 17-21], Orgill and Bodner explained that limitations of analogies were common for science textbooks examined for the use of analogies [20].

Teaching-with-analogies (TWA), proposed by Glynn [22], is a well-known systematic approach concerning analogy use in science classes. In this method, the target is first introduced. Then, students' knowledge regarding the analog is examined and they are reminded of this analog. Third, relevant features of the analog are identified and 
Family Relationship Analogy for the Photoelectron Emission

One of the important experiments in quantum physics is the photoelectric effect. It explains why photoelectrons are emitted from a metal surface by a specific light beam, irrespective of how intense it is, and illustrates the particle nature of light. "If it is a wave, a wave comes propagating space wave fronts and hits the surface. Another wave hits the surface and another wave hits the surface. In order to break off an electron from the surface, you need time" [8]. However, there is no time interval for the emission of the photoelectron from the surface. "Maybe you see this type of event when getting permission from your father" [8]. Let us discuss what happens when you are gaining permission from your father. For example, you may obtain permission after significant effort or you may receive it easily. "You need to ask several times to get permission. You need to go easy on your father before getting permission and you need time for this. However, sometimes just one word is enough to get the permission from your father without spending much time. This is what you told him, and you got the permission!" [8]. From the classical viewpoint, light is considered to be a wave, and an electron can be ejected from a metal surface after a while by increasing the intensity of the light beam. This process is similar to asking your father multiple times to get permission. However, "This is quantum physics! This is a new explanation. Welcome new physics! Welcome new habits! With this new explanation, to break off the electron from the surface, you do not need to wait. Just a certain frequency of the incident light is enough to break off the electron from the surface" [8]. Therefore, this process is very similar to gaining permission by saying just one word to your father! Due to this analogy from daily life, two situations are possible in terms of getting permission from your father: You can either get it after requesting for a long time and just saying one word. However, in physics, photoelectron emission is possible with a certain frequency of light, indicating the quantized nature of energy rather than how intense light is. In conclusion, the frequency of the incoming light beam is important for photoemission of the electrons from the metal surface, rather than the intensity of incoming light. Hence, the photoelectric effect is tightly connected to quantum physics because it illustrates that energy packets have a particular quantized energy and further explains the particle nature of light.

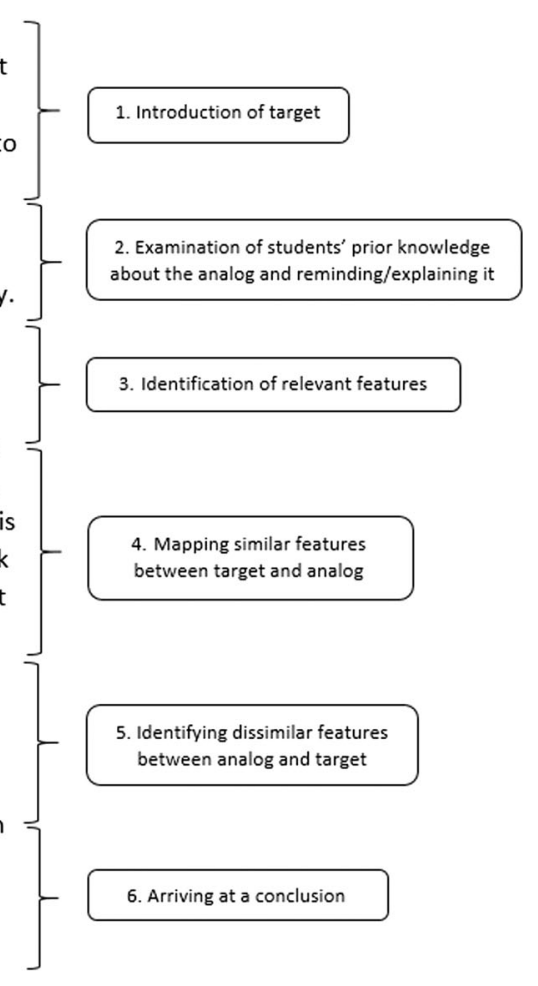

FIG. 1. An analogy with TWA steps for the photoelectron emission. This analogy, named the family relationship analogy, was originally presented in Didiş's [8] study investigating the analogies used in the teaching of introductory quantum theory. While the quoted parts were taken directly from Didiş [8], a relevant text was added to improve the analogy by TWA steps.

similarities between target and analog are mapped. Finally, a conclusion is drawn for the target and dissimilarities between analog and target are examined [4,5,8,9,22-25]. The order of the last two steps of this approach are sometimes exchanged (i.e., first examination of dissimilarities between analog and target occurs, then arriving at a conclusion about the target $[4,23])$. Revision of the "family relationship analogy" [8] that was used by a physics professor in an undergraduate level modern physics course can be an example for the implementation of TWA. This analogy was a spontaneously constructed analogy in the teaching of a quantum view of photoelectron emission from the metal surface and also aimed to discriminate classical and quantum viewpoints. Presentation of this analogy with TWA steps [23] is presented in Fig. 1.

As seen in Fig. 1, three issues commonly occur with respect to analogy use in science classes with Glynn's TWA approach: (i) pretopic orientation, involving explanation of the analog and a strategy indicating the analogical nature, (ii) level of enrichment, which is the richness of mapping between analog and target, and (iii) limitation of the analogy, which provides an explanation of dissimilarities between analog and target $[4,5,22,23,25]$.

Pretopic orientation is important because in some cases students may have problems when relating analog and target [39], potentially visualizing analogs differently than the teacher had explained them (particularly analogs not familiar to students), and this causes misconceptions [24]. Mapping between analog and target is fundamental as the analogy is constructed because it presents similar attributes between both, indicates the relationship, and explains why the analog and target are similar [5,25]. Although analogies share common attributes, the analog and target are different and have varying attributes. Limitations of analogies correspond to their dissimilar characteristics. It is important to mention these limitations as well as common attributes between both analog and target when analogies are constructed $[11,12,24]$.

As well as the use of analogy in science teaching, it is important to identify how it is used. Hence, in this study, we focus on analogies used in elementary science textbooks. With the identification of the analogies used for teaching physics, chemistry, biology, and engineering, we also have a chance to compare the qualities of analogies for these domains. Then, we discuss how analogies can be improved for teaching physics subjects.

\section{METHODOLOGY}

For this study, six science textbooks from 3rd to 8th grades approved for use in the 2017-2018 academic year by the Ministry of Education in Turkey were subjected to 
content analysis [40]. Then, analogies used in the textbooks were identified.

Content analysis is a systematic and repeatable technique summarizing both written materials such as books, letters, and newspapers and visual materials such as videos and photographs based on specific coding categories [40]. For this reason, it was the best suited analysis for this research. In the analysis, the steps given in Ylldırım and Şimşek [40] were followed. These were, after the selection of the sample (all of six science textbooks from 3rd to 8th grade), coding categories were developed for determination of analogies (to discriminate them from examples, models etc.), their characteristics, and qualities due to TWA. Then the unit of analysis was determined and the analogies were identified. Finally, the analysis results were quantified.

During this analogy identification process in content analysis, the words gibi (as) and benzer (like) were scanned in the textbooks. Explanations indicating relationships between a known and an unknown were considered to be an analogy. Each meaningful unit indicating a relationship was considered the analysis unit in the coding of analogies in the textbooks. The analogies' explanation of an unscientific concept (e.g., roads are similar to networks), explanation of a real situation (the heart is a pump), examples, models, analogy-based scientific terminology (cancellous bone), and analogy-based widespread explanation (a meteor shower as a shooting star) were not considered analogies. Then, the way in which analogies were used in textbooks was identified and their characteristics were determined in light of the literature (i.e., content, location, analogical relationship, presentation format, level of abstraction, position, level of enrichment, pretopic orientation, limitation, source domain, presentation medium, and aim of use [5,25]). Three of these widely examined characteristics of the analogies were fundamental steps for TWA. Then, each identified analogy was then reexamined in terms of three elements also pointed out in Glynn's TWA [22]: pretopic orientation, level of enrichment, and explanation of limitation of the analogy. If none of these three elements existed, that analogy was termed "poor"; if one or two elements existed, that analogy was called "moderate"; if all of three elements existed, the analogy was referred to as "good."
For each of the three elements, one point was assigned: good analogies were coded with three points because they state dissimilar characteristics of the analogies as well as shared attributes (explanation of limitations), presenting enriched or extended mapping by explaining which attributes were shared and how they were related (level of enrichment), and explaining the analog and analogical strategy (pretopic orientation). If the analogy comprised one or two of them (i.e., moderate analogy) one or two points were assigned. If the analogy stated neither shared attributes enriched or extended manner (level of enrichment) nor dissimilar characteristics (limitations) and did not explain the analog, no points were assigned. This analogy is simply stated and poor because the analog and mapping is limited for the explanation of the target and provides limited information to students.

After qualification of each analogy by considering Glynn's approach, examples were presented regarding how they could be developed in science teaching.

During the research, reliability and validity precautions were taken. While expert opinions were obtained for the appropriateness, description, and mutual exclusiveness of the codes (discrimination of the codes each other) for the validity of coding, reliability coefficients were calculated. The interrater reliability coefficient for the data analysis was 0.88 for ten analogies among 141 at first, then full agreement of the authors was obtained after discussing the discrepancies. The intracoder reliability coefficient was 0.97 between two successive coding sessions of the second author by waiting four weeks.

\section{ANALOGIES IN SCIENCE TEXTBOOKS}

In this research, 141 analogies were identified in science textbooks from 3rd to 8th grades in Turkish elementary schools. Distribution of the qualifications of analogies from 3rd to 8th grade science textbooks is presented in Table I.

As shown in Table I, most analogies were moderate (86 of $141,61.0 \%$ ). Such analogies comprise a minimum of one and a maximum of two elements of three fundamental elements. By considering the existence of three elements, only one analogy exists in the 6th grade $(0.7 \%)$ in the good category. The other analogies (54 of 141, 38.3\%) were in the poor category because they had none of the three

TABLE I. Qualifications of the analogies used in science textbooks (from 3rd to 8th grades) due to the elements in Glynn's TWA approach. Poor analogy means none of the TWA elements existed; moderate analogy means one or two elements of TWA existed, and good analogy means all three elements of TWA existed.

\begin{tabular}{|c|c|c|c|c|c|c|c|}
\hline $\begin{array}{l}\text { Grade } \\
\text { qualification }\end{array}$ & $\begin{array}{c}\text { 3rd grade } \\
\text { number }(\%)\end{array}$ & $\begin{array}{c}\text { 4th grade } \\
\text { number }(\%)\end{array}$ & $\begin{array}{c}5 \text { th grade } \\
\text { number }(\%)\end{array}$ & $\begin{array}{c}\text { 6th grade } \\
\text { number }(\%)\end{array}$ & $\begin{array}{c}7 \text { th grade } \\
\text { number }(\%)\end{array}$ & $\begin{array}{c}\text { 8th grade } \\
\text { number }(\%)\end{array}$ & $\begin{array}{c}\text { Total } \\
\text { number }(\%)\end{array}$ \\
\hline Poor & $12(66.7 \%)$ & $10(38.5 \%)$ & $11(45.8 \%)$ & $6(27.3 \%)$ & $1(4 \%)$ & $14(53.8 \%)$ & $54(38.3 \%)$ \\
\hline Moderate & $6(33.3 \%)$ & $16(61.5 \%)$ & $13(54.2 \%)$ & $15(68.2 \%)$ & $24(96 \%)$ & $12(46.2 \%)$ & $86(61.0 \%)$ \\
\hline Good & 0 & 0 & 0 & $1(4.5 \%)$ & 0 & 0 & $1(0.7 \%)$ \\
\hline
\end{tabular}




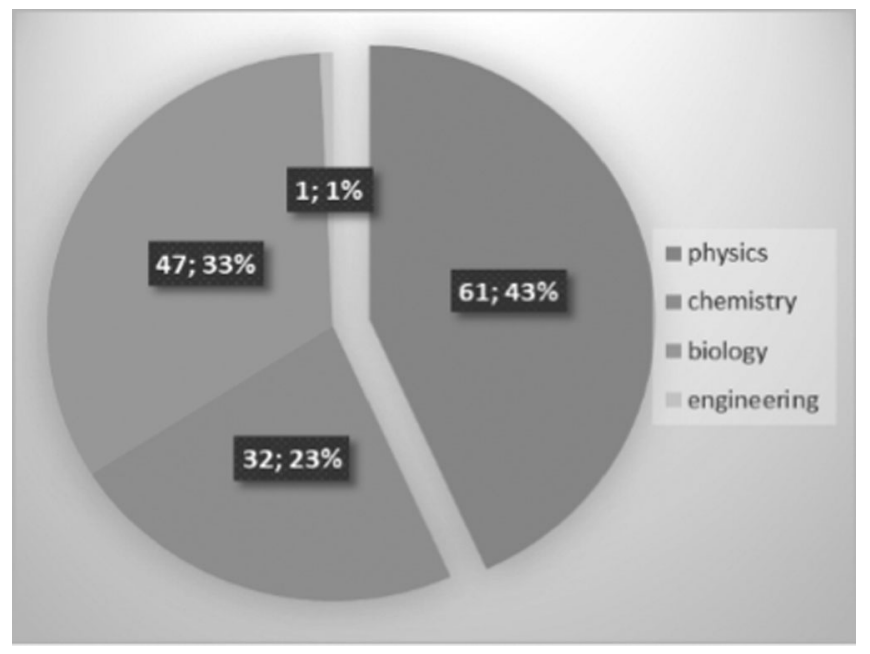

FIG. 2. Distribution of the analogies used in science textbooks among the disciplines.

characteristics. When the qualifications of analogies for different grade level science textbooks were examined, the 7 th grade textbook used analogies better than the others ( 24 of 25 were moderate). Figure 2 presents the distribution of the analogies among the disciplines.

Figure 2 shows most of the analogies were used in the teaching of physics concepts (61 of 141, 43\%) comparing with biology, chemistry, and engineering concepts. Among 61 physics analogies, 33 of them are poor (54.1\%), 27 of them are moderate $(44.3 \%)$, and one of them is good (1.6\%). The analysis of the qualifications of the analogies by discipline indicated that most analogies in chemistry (24 of 141, 75.0\%), biology (34 of 141, 72.3\%), and engineering ( 1 of $141,100 \%)$ were in the moderate category; however, in physics, most of the analogies (33 of 141, 54.1\%) were poor. In addition, most poor analogies were used in teaching physics topics, with only one good analogy being used in this field.

These findings indicate that the analogies used in elementary science textbooks do not contain the important elements in analogy use, and so they are rather limited. When students read such analogies in the textbooks, they may help their understanding; however, science teachers should consider important elements in the literature and improve analogies for effective teaching.

\section{IMPROVEMENT OF TEXTBOOK ANALOGIES FOR TEACHING PHYSICS CONCEPTS}

This section presents some examples for the improvement of poor and moderate analogies for physics topics. The first analogy was for the teaching of gravitational force, and the other one was about electrical conductivity. The first analogy is used in the 7th grade science textbook: "This force is similar to the force applied by the different poles of two magnets to each other" [41] (p. 70). This analogy has the following characteristics: It provides a comparison of an abstract target with an abstract analog; the mapping was rich with the statement of similarity and it was functional; it was used in the middle of the teaching of the topic as an embedded activator, without any pretopic orientation, in plain text with a verbal-pictorial format. The textbook used this analogy to clarify the taught concept, with an environmental characteristic, and without stating the limitation of the analogy. By considering Glynn's elements regarding analogy use, this analogy is moderate with enriched mapping (it had a lack of pretopic orientation and statement of limitations). This analogy is critical for students' learning of gravity and can be used as follows with improvement for teaching. With this aim, Fig. 3 presents the use of analogy in the textbook with directly translated and revised versions together by indicating the TWA steps.

As seen in the textbook use, the analogy does not contain information about the analog (magnetism). Because magnets are well known by 7 th grade students, the textbook author may not describe the magnet when constructing the analogy. However, it would be helpful to state that it was just a strategy to show the similarity of attractiveness and that they (magnetic and gravitational forces) are not related to each other. Although this analogy was used to clarify the gravitational force concept, students may sometimes relate magnetic forces to gravitational ones, having a misconception because "Magnetic field lines keep the human body on the surface of the earth" [42]. They may even consider that one causes the other by saying that gravitational force is caused by a magnet at the center of Earth. Therefore, although the "field" concept is common for them, it should be stated they do not create each other in addition to the explanation of different features of the analog (i.e., repulsive force).

Twenty-four (17\%) of the 141 analogies identified in the science textbooks (one analogy in the 4th grade, four analogies in the 5th grade, five analogies in the 6th grade, 11 analogies in the 7th grade, and three analogies in the 8th grade) were analogical models (i.e., analogy-based activities [23]) that can be used in the class during science teaching. For such activities, the target is related to the relevant feature of the model (analog). Hence, it is important for students to have experience of the analogical models in the classes. There are also some examples for the improvement of analogical models used in the science textbooks which have potential to be used in science classes.

An analogical model used in the 6th grade science textbook is a famous analogy: "In an electric circuit, transfer of the energy can be considered as the flow of water in the pipes" [43] (p. 211). This analogical model has the following characteristics: It is the extended explanation of an abstract target with a concrete analog that is both structural and functional. The analogy was used in plain 


\section{Old text in the textbook}

"The effect on a bouncing child to make him fall toward the ground; the effect on a kicked ball to make it move upward decelerating and downward accelerating are all forces. This force is similar to the force applied by the different poles of two magnets to each other. When the opposite poles of the magnets are placed closely, they act on each other as an attractive force. Accordingly, the Earth applies an attractive force to the objects on itself and the objects on the Earth apply attractive force to the Earth. However, the mass of the Earth is relatively large; the Earth does not move but the objects on the Earth moves toward it. The force between the objects on the Earth and the Earth is termed gravitational force. The gravitational force acting on objects on the Earth is referred to as 'weight'." [41, p. 70].

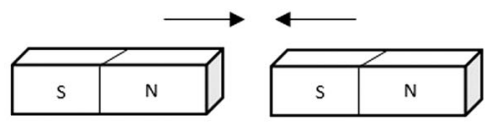

\section{Revised text due to TWA}

Gravitational force is an action-at-a-distance force. For example, the falling of a bouncing child toward the ground or moving of a kicked ball upward decelerating and downward accelerating. This type of force acts attractively without contact. What may be another example for this type of force? Magnetic force between magnets! Magnets have two poles; North (N) and South (S). If opposite poles of the magnets are placed together without contact, they attract each other. Gravitational force is similar to the force applied by the different poles of two magnets to each other. Thus, both gravitational and magnetic forces between the opposite poles of magnets are attractive.
4. Mapping similar features between target and analog

5. Identifying dissimilar features between analog and target

6. Arriving at a conclusion Due to the magnetic force between the opposite poles of magnets, the Earth and objects on the Earth attract each other. This force is referred to as gravitational force. Because the mass of the Earth is relatively large, objects on it move toward its center, such as the case of a ball falling toward the Earth after being kicked. However, while different magnet poles exert an attractive force on each other, the same poles exert a repulsive force. As a result, while a magnetic force can be attractive or repulsive, the gravitational force is always attractive. In conclusion, gravitational force is - an attractive force acting at a distance.

FIG. 3. Revised version of the analogy used in the 7th grade textbook [41] (p. 70) due to TWA. The textbook is originally in Turkish and the analogy was presented with magnet figures. So the text explaining the analogy was translated and the magnet figures were redrawn similar to the ones given in the textbook.

\section{Old text in the textbook}

"In an electric circuit, one of the variables affecting the brightness of the bulb is the kind of conducting material. The flow of water in different pipes of the same length and width is shown in the figure shown aside. The difference in the quantity of water accumulated in the cups in a time interval is due to the structure of the pipes. While the water flows easily through the straight pipe, it flows difficultly in a curled pipe. In an electric circuit, transfer of the electrical energy can be considered as the flow of water in the pipes. The transfer of electrical energy can be easy or relatively difficult due to the nature of the particular conducting material. In the activity, you observed the change in the bulb's brightness depending on the kind of the conducting material. If the kind of the conducting material changes, the electrical conductivity also changes. Some of the conductors make the energy transfer more difficult. The bulb brightness decreases in the circuits with these conductors. Electrical energy moves through the conducting wire relatively easily, allowing the bulb to glow as a bright light. Some conductors such as silver and copper conduct electricity more efficiently." [43, p. 211].

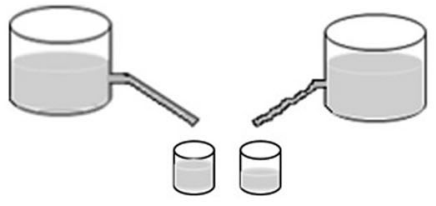

\section{Revised text due to TWA}

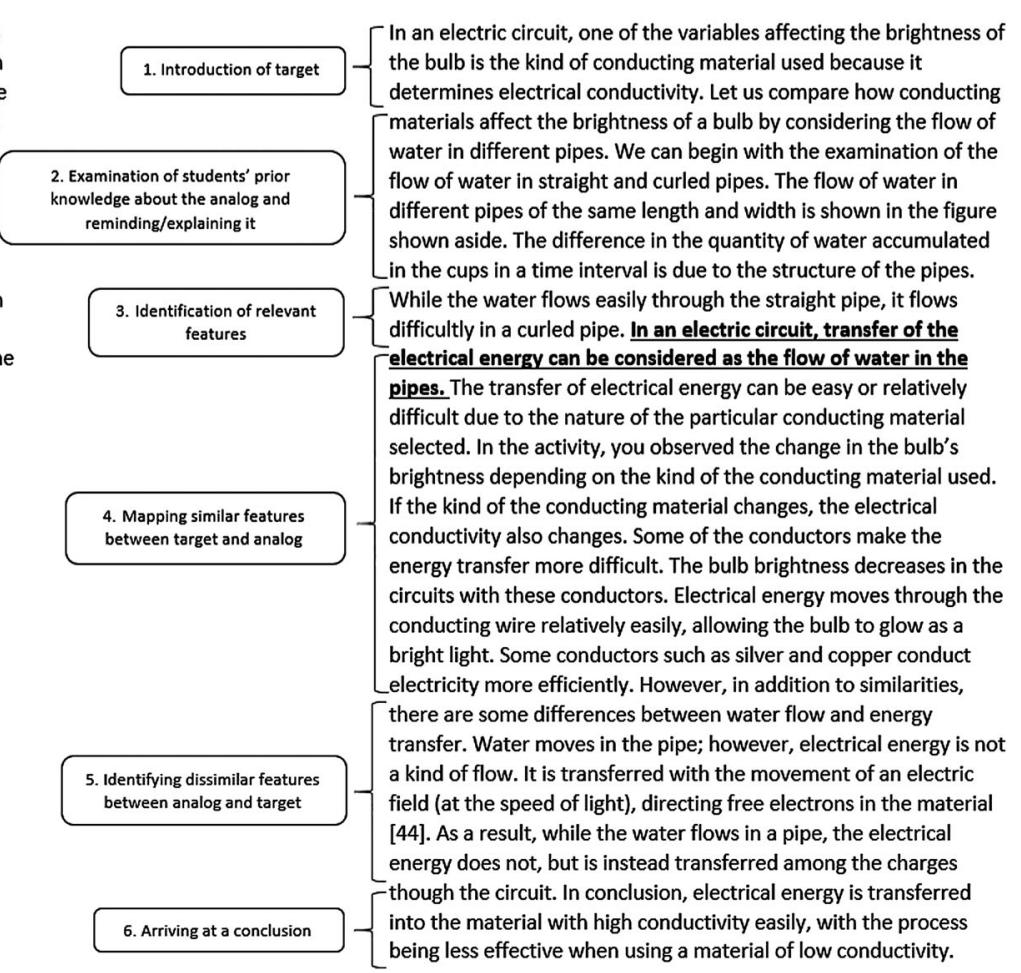

FIG. 4. Revised version of the analogy used in the 6th grade textbook [43] (p. 211) due to TWA. The textbook is originally in Turkish and the analogy was presented with tub figures. So the text explaining the analogy was translated and the tub figures were redrawn similar to the ones given in the textbook. 
text with both the verbal and pictorial format in an embedded activator. The analog was explained to discriminate concepts about conductivity. It had an environmental characteristic without explaining the analogy's limitation. This analogy was in the moderate category, with one point assigned for pretopic orientation and another for extended mapping. This analogy can be improved for science classes with stating the parts that the analogy breaks. Figure 4 presents how this analogy was used in the textbook and how it could be revised by TWA steps.

As given in Fig. 4, this moderate analogy had explanations about the analog and extended mapping. However, improvement of the statement of limitations of the analogy to students is required. This analogy is also critical for students' understanding of current and electrical energy transfer because sometimes students may have misconceptions such as "Electrons move with the speed of light" [42] to explain the question "How does the bulb lighten immediately when it is turned on?" Hence, they consider that electric charges, together with the energy, flow in the material at the speed of light. For this reason, dissimilarity between the transfer of electrical energy and the flow of water in a pipe should be discussed with students. It should be made clear to students that, while the speed of electrical energy transfer is about that of light, the speed of electrons is quite small [44].

One physics analogy among 141 in elementary science textbooks was categorized as good. It was used in the 6th grade as follows: "If you throw your ball, like the child in picture, towards the wall, it bounces and comes back to you... (text)... Reflection of sound can be considered as the bounce of a ball hitting on the wall." [43] (p. 138).

This analogy relates an abstract target with a concrete analog with enriched mapping explaining the structural similarity. It explains the analog in plain text in a verbalpictorial format at the beginning of the topic as an advanced organizer. It was used to clarify sound propagation with an environmental characteristic. Different from the analogies previously discussed, this analogy states the limitation of the bouncing ball analogy for the explanation of sound propagation as follows: "However, while some of the sound waves transferred through the wall, some parts of them reflect back" [43] (p. 139). As a result, with consideration of the three elements of Glynn, this analogy was the only good one among others in the science textbooks.

\section{CONCLUSION, DISCUSSION, AND SUGGESTIONS}

As the literature indicates, analogies are similar to double-edged swords and they should be used carefully to prevent students developing misconceptions [6,8-11]. Thus, as well as which analogies are used in science teaching, how such analogies are used should be identified $[11,21]$. In this way, missing parts of the analogies or the situations that have potential to cause misconceptions may be prevented by improvement of them by teachers and their effectiveness may be increased.

This study indicated that some of the analogies used in science textbooks in the elementary level were not good, but mostly moderate due to not considering some important points discussed in Glynn's TWA [4,22,23]. Some of the analogies were poor because they did not consider any of the important elements that should be taken into consideration in the use of analogies. This study presented some examples about how the analogies could be improved by science teachers.

Regarding the qualifications of analogies used in different grade level science textbooks, the 7 th grade textbook used analogies better than the others (24 of 25 were moderate). In addition, most of the analogical models used in the 7th grade had better use of analogies than the others, which may be explained by the use of analogical models focusing on pretopic orientation and extended mapping. Almost all analogies were rated moderate except one in the 7 th grade textbook. This result may also be the preference of authors, in other words, different publishers [18].

In this study, $17 \%$ of textbook analogies were found to be analogical models that can be used in science classes [23]. Because the comparison for a target is made with the model element (as an analog), use of these activities in science classes is important. Otherwise, students may not understand models unfamiliar to them, so they may not understand the analogy. Hence, they should be used by science teachers with improvements to the missing parts in classes by making students active both mentally and physically. In this manner, its effectiveness may be increased, which could help students make sense of abstract concepts.

Although most science textbook analogies were used in the explanations of physics topics, most of the poor analogies were used in physics; thus, most physics analogies were poor. The analysis indicated that while poor analogies lack pretopic orientations, sufficient mapping between analog and target, and did not provide a statement of limitation of analogies, moderate analogies mainly lacked the last part (i.e., an explanation of limitations that the analogy breaks). This common feature of poor and moderate analogies suggests the improvement of analogies by stating dissimilar characteristics as well as similar features that are mapped in the construction of analogies $[4,5,11,22,23,25]$. Textbook authors should also consider the other two elements to present good analogies: (i) enrichment of mapping shared features of the analog and target, and (ii) explanation of the analog or strategy for pretopic orientation. Because they provide more information to students about the analogy, they improve students' understanding of the target concept and prevent misconceptions $[6,11,12]$.

Further, science teachers should also consider these issues and use analogies with the improvement of missing parts in the textbook analogies in their science classes, 
rather than using them directly in the textbook. Hence, it is suggested that they should revise or reorganize textbook information when teaching.

As a final statement based on findings concerning the characteristics of the textbook analogies and literature, teachers should (i) select an appropriate analog for students and provide relevant explanations about the analogs, (ii) map the shared features between the analog and target clearly and avoid stating "it is something like" and (iii) state that an analog is not the reality of the target but it is a kind of explanation sharing similarities with the target.
Therefore, the limitation of the analogies and unshared features of the analog and target should be noted by the teachers while teaching with analogies.

\section{ACKNOWLEDGMENTS}

We appreciate Professor Dr. Ali Azar and Associate Professor Dr. Eralp Bahçivan for their precious feedback and thank to Zonguldak Bülent Ecevit University, Turkish Academy of Sciences (TÜBA-GEBİ/2017), and Scientific and Technological Research Council of Turkey.
[1] T. Kesercioğlu, H. Yılmaz, P. Huyugüzel Çavaş, and B. Çavaş İlköğretim fen bilgisi öğretiminde analojilerin kullanımı: "Örnek uygulamalar”, Ege Eğitim Dergisi 5, 35 (2004); http://dergipark.gov.tr/egeefd/issue/4920/67311.

[2] R. K. Coll, B. France, and I. Taylor, The role of models/ analogies in science education: Implications from research. Int. J. Sci. Educ. 27, 183 (2005).

[3] S. M. Glynn, Making science concepts meaningful to students: Teaching with analogies (2008), http://blogs .oregonstate.edu/smed1112/files/2011/10/Glynn2008 MakingScienceConceptsMeaningful.pdf.

[4] S. M. Glynn and T. Takahashi, Learning from analogy enhanced science text, J. Res. Sci. Teach. 35, 1129 (1998).

[5] R. B. Thiele and D. F. Treagust, The nature and extent of analogies in secondary chemistry textbooks, Instr. Sci. 22, 61 (1994).

[6] A. G. Harrison and D. F. Treagust, Teaching and learning with analogies, in Metaphor and Analogy in Science Education, edited by P. J. Aubusson, A. G. Harrison, and S. M. Ritchie (Springer Netherlands, 2006), pp. 11-24.

[7] Z. R. Dagher, The case for analogies in teaching science for understanding in Teaching Science for Understanding; A Constructivist View, edited by J. J. Mintzes, J. H. Wandersee, and J. D. Novak (Academic Press, New York, 1998).

[8] N. Didiş, The analysis of analogy use in the teaching of introductory quantum theory, Chem. Educ. Res. Pract. 16, 355 (2015).

[9] G. Harman and A. Çökelez, Analojilerin fen eğitimindeki yeri ve önemi, Necatibey Ĕ̆. Fak. Elektr. Fen ve Mat. Eği. Derg. 11, 340 (2017).

[10] K. S. Taber, When the analogy breaks down: Modelling the atom on the solar system, Phys. Educ. 36, 222 (2001).

[11] D. F. Treagust, S. M. Stocklmayer, A. Harrison, G. Venville, and R. Thiele, Observations from the classroom: when analogies go wrong, Res. Sci. Educ. 24, 380 (1994).

[12] D. F. Treagust, A. G. Harrison, and G. J. Venville, Teaching science effectively with analogies: an approach for preservice and in service teacher education, J. Sci. Teach. Educ. 9, 85 (1998).

[13] A. Abak, A. Eryılmaz, S. Yılmaz, and M. Yılmaz, Effects of bridging analogies on students' misconceptions about gravity and inertia, Hacettepe Ün. Ĕ̆. Fak. Derg.
20, 1 (2001); http://www.efdergi.hacettepe.edu.tr/shw_ artcl-1011.html.

[14] N. Azizoğlu, S. Aslan, and S. Pekcan, Periyodik sistem konusu ve analojilerle öğretim modeli: Yöntem, cinsiyet ve motivasyon faktörlerinin öğrenci başarısına etkisi, İlköğr. Onl. 14, 472 (2015); http://ilkogretim-online.org.tr/index .php/io/article/view/1286.

[15] İ. Bilgin and Ö. Geban, Benzeşim (analoji) yöntemi kullanarak lise 2. sinıf öğrencilerinin kimyasal denge konusundaki kavram yanılgılarının giderilmesi, Hacettepe Ün. Ĕ̆. Fak. Derg. 20, 26 (2001); http://www .efdergi.hacettepe.edu.tr/shw_artcl-1013.html.

[16] S. Kobal, A. Şahin, and İ. Kara, Fen ve teknoloji dersinde analojilere dayalı öğretimin öğrencilerin başarıları ve hatırda tutma düzeyi üzerindeki etkisi, Pamukkale Ün. Ĕ̆. Fak. Derg. 36, 151 (2014); http://dergipark.gov.tr/ pauefd/issue/32869/374886.

[17] N. Azizoğlu, M. Çamurcu, and V. N. Kırtak Ad, Ortaöğretim fizik ders kitaplarında analojilerin kullanımı: Belirleme ve sınıflandırma çalışması, Türk Fen Eği. Derg. 11, 39 (2014); http://www.tused.org/internet/tused/ ARCHIVE/v11/i2/tusedv11i2s2.pdf.

[18] M. Çalık and E. Kaya, Fen ve teknoloji ders kitaplarında ve öğretim programındaki benzetmelerin incelenmesi, İlköğr. Onl. 11, 856 (2012); http://ilkogretim-online.org.tr/index .php/io/article/view/1451/1307.

[19] P. Demirci Güler and R. Yağbasan, Fen ve Teknoloji ders kitaplarında kullanılan analojilerin ve analojilere ilişkin sorunların betimlenmesi, İnönü Ün. Ĕg. Fak. Derg. 9, 105 (2008); http://dergipark.gov.tr/inuefd/issue/8707/108707.

[20] M. Orgill and G. M. Bodner, An analysis of the effectiveness of analogy use in college-level biochemistry textbooks, J. Res. Sci. Teach. 43, 1040 (2006).

[21] R. B. Thiele, G. J. Venville, and D. F. Treagust, A comparative analysis of analogies in secondary biology and chemistry textbooks used in Australian schools, Res. Sci. Educ. 25, 221 (1995).

[22] S. M. Glynn, Teaching science with analogies: A strategy for teachers and textbook authors (National Reading Research Center Athens, GA, 1994).

[23] S. M. Glynn, Methods and strategies: The teachingwith-analogies model, Sci. Child. 44, 52 (2007); 
https://common.nsta.org/resource/?id=10.2505/4/sc07_044_ 08_52.

[24] A. G. Harrison and D. F. Treagust, Teaching with analogies: A case study in grade-10 optics, J. Res. Sci. Teach. 30, 1291 (1993).

[25] R. B. Thiele and D. F. Treagust, An interpretive examination of high school chemistry teachers' analogical explanations, J. Res. Sci. Teach. 31, 227 (1994).

[26] N. S. Podolefsky and N. D. Finkelstein, Analogical scaffolding and the learning of abstract ideas in physics: an example from electromagnetic waves, Phys. Rev. ST Phys. Educ. Res. 3, 010109 (2007).

[27] I. Aykutlu and A. İ. Şen Fizik, Öğretmen adaylarının analoji kullanımına ilişkin görüşleri ve elektrik akımı konusundaki analojileri, Hacettepe Ün. Ĕ̆. Fak. Derg. 41, 48 (2011); http://www.efdergi.hacettepe.edu.tr/shw_artcl-679.html.

[28] S. Demir, F. Önen, and F. Şahin, Fen bilgisi öğretmen adaylarının bakış açısıyla analojiler, Necatibey Eğ. Fak. Elektr. Fen ve Mat. Eği. Derg. 5, 86 (2011); http:// dergipark.gov.tr/balikesirnef/issue/3373/46554.

[29] E. Ekici, F. Ekici, and F. Aydın, Fen bilgisi derslerinde benzeşimlerin (analoji) kullanılabilirliğine ilişkin öğretmen adaylarının görüşleri ve örnekleri, Ahi Evran Ün. Kırşehir Ĕ . Fak. Derg. 8, 95 (2007); http://kefad.ahievran.edu.tr/ Kefad/ArchiveIssues/PDF/2c2e2a13-8d55-e711-80ef00224d68272d.

[30] S. M. Nashon, The nature of analogical explanations: high school physics teachers use in Kenya, Res. Sci. Educ. 34, 475 (2004).

[31] D. F. Treagust, R. Duit, I. Lindauer, and P. Joslin, Teachers' use of analogies in their regular teaching routines, Res. Sci. Educ. 19, 291 (1989).

[32] J. J. Clement, Expert novice similarities and instruction using analogies, Int. J. Sci. Educ. 20, 1271 (1998).
[33] M. Orgill and G. Bodner, What research tells us about using analogies to teach chemistry, Chem. Educ. Res. Pract. 5, 15 (2004).

[34] K. M. Pittman, Student-generated analogies: Another way of knowing, J. Res. Sci. Teach. 36, 1 (1999).

[35] N. S. Podolefsky and N. D. Finkelstein, Use of analogy in learning physics: The role of representations. Phys. Rev. ST Phys. Educ. Res. 2, 020101 (2006).

[36] H. Akkuş, Kimyasal tepkimelerin dengeye ulaşmasının öğretiminde kullanılabilecek bir analoji: Meslek seçimi analojisi, Atatürk Ün. Kazım Karabekir Eğ. Fak. Derg. 14, 19 (2006); http://e-dergi.atauni.edu.tr/ataunikkefd/article/ view/1021004119.

[37] M.S. Kovacevic and A. Djordjevich, A mechanical analogy for the photoelectric effect, Phys. Educ. 41, 551 (2006).

[38] M. Whalley, The photoelectric effect: A useful sporting analogy, Phys. Educ. 40, 503 (2005).

[39] D. Heywood and J. Parker, Confronting the analogy: primary teachers exploring the usefulness of analogies in the teaching and learning of electricity, Int. J. Sci. Educ. 19, 869 (1997).

[40] A. Yıldırım and H. Şimşek, Nitel Araştırma Yöntemleri (Seçkin, Ankara, 2005).

[41] E. Tuncel, Ortaokul fen bilimleri 7 ders kitabı (Mevsim Yayıncılık, Ankara, 2017).

[42] B. Güneş, Fizikteki Kavram Yanılgıları (2015), http://w3 .gazi.edu.tr/ bgunes/files/kavramyanilgilari/fizikte\%20sik \%20rastlanilan\%20kavram\%20yanilgilari.html.

[43] N. Gökçe and N. Işık, Ortaokul fen bilimleri ders kitabı 6 (Tuna Matbaacilık, Ankara, 2017).

[44] B. Güneş, Fizikte Kavram Yanılgıları (Palme Yayıncılık, Ankara, 2017). 